\title{
11. Is ethics important for economic growth?
}

\author{
David Rea
}

\section{Introduction}

Over the last four decades, living standards in New Zealand have fallen far behind those in Australia. ... The Prime Minister has articulated his vision of closing the gap with Australia by 2025. We share that vision. New Zealand has vast potential: strong institutions, hardworking and creative people, a degree of trust and integrity second to none in the world, and abundant natural resources. So of course the gap can be closed. But it won't close of its own accord. And if nothing is done the gap could get worse, with increasingly serious long-term implications for our country's future. Starting from here, closing the gap will require farreaching policy reforms. That will take bold courageous leadership over at least the next decade. (2025 Taskforce 2009, p. 3, emphasis added)

In its first report, the 2025 Taskforce (2009) observed that trust and integrity are important factors determining economic growth. However, despite this observation, the taskforce did not recommend that government should encourage business, workers, or consumers to be more ethical or trustworthy. The taskforce seems to have been of the view that because New Zealand already had the world's highest levels of trust and integrity, no major change in economic policy in this area was needed.

The aim of this chapter is to look more closely at this intriguing and somewhat unusual area of economic policy. The chapter first looks at indicators of ethical behaviour in New Zealand, and then reviews the theory and evidence about the extent to which 'ethical behaviour' might be important for the economy. Lastly, the chapter considers the public policy implications of the finding that ethical behaviour might be important for economic growth.

This chapter is organised around the following questions.

- How should we conceptualise ethical behaviour in an economic context?

- How ethical or trustworthy are New Zealanders? 
- Is ethical behaviour important for economic efficiency and economic growth?

- Is there any evidence that New Zealand's economic performance would improve if we were more ethical?

- Should economic policy aim to foster ethical or trustworthy behaviour?

The focus of this chapter is the relationship between ethical behaviour and economic efficiency. This focus is rather narrow and neglects other important reasons why such behaviour might be important. Ethical behaviour in particular might lead to a 'fairer' distribution of resources, and trustworthy behaviour might improve the quality of relationships between people in the community. This chapter is not an argument that these outcomes are unimportant. Instead, the chapter asks whether, in addition to these issues, we should also be concerned about ethical behaviour because it might enhance economic performance.

The rest of the chapter is structured as follows. The next section defines ethical behaviour in an economic context. The third section looks at the prevalence of ethical behaviour in the New Zealand. The fourth section summarises advances in economic theory that suggest that ethical behaviour is important for the economy. The fifth section looks at whether there is any evidence to suggest that improving ethical behaviour would enhance New Zealand's economic performance. The sixth section looks at the public policy implications of these findings. The final section provides concluding comments.

\section{What is ethical behaviour in an economic context?}

The key to the nature of ethical behaviour is that it involves an individual or organisation acting in a manner that is considerate of others. An agent acts ethically where they choose a course of action where the welfare of others is given some appropriate moral consideration. In a descriptive sense, ethical behaviour typically involves using some moral principles as a guide for decision making.

Ethical behaviour stands in contrast to the behaviour that is traditionally assumed in economics. Traditionally, economists have assumed individuals are almost entirely selfish and frequently act in a way that benefits only themselves. It is typically assumed that most individuals are unethical and - if they can get away with it - will lie, cheat, or steal for their own personal gain.

However, in contrast to the theory, in the real world many people seem to act in trustworthy or ethical ways. For example: 
- it is not uncommon to observe customers who have been undercharged for goods volunteering this information to shop assistants

- many individual and firms pay the expected amount of tax on their income, despite opportunities to use tax loopholes and avoidance mechanisms

- many people go beyond what is strictly required in their employment contracts because they want to do a good job.

Actual behaviour occurs for a variety of reasons, and it is important to distinguish between 'good' behaviour that occurs because of a motivation 'to do the right thing' and 'good' behaviour that occurs for more selfish reasons. Consider, for example, observing the speed limit in a car. For some people obeying this law is the 'right thing to do'. Others might act lawfully, but only because of the risk of penalties if they are caught and prosecuted. In this chapter, I am particularly interested in 'ethically motivated behaviour' because it is a low cost means of ensuring people do the right thing, and avoids the need to create private or public systems of incentives to ensure appropriate behaviour.

\section{How much ethical behaviour is there in New Zealand?}

Measuring the extent to which individuals are ethical is somewhat problematic for several reasons. Defining ethical behaviour in any particular situation is difficult, and it is not something amendable to straightforward measurement.

However, notwithstanding these difficulties, I have identified eight indicators that provide information about levels of ethical behaviour in New Zealand. These indicators also provide the same information for 25 other countries, so comparisons can be made. The indicators are as follows.

The level of perceived corruption among politicians and public officials in different countries: This indicator is an index that Transparency International developed based on a range of expert and business surveys. The data is drawn from the Corruption Perceptions Index 2008 (Transparency International 2009).

Ethical behaviour indicators drawn from the fifth wave of the World Values Survey: These four indicators are the extent to which people believe it is not justifiable to cheat on their taxes, accept a bribe, claim government benefits to which they are not entitled, and avoid a fare on public transport. The surveys were conducted over 2004 to 2008. The New Zealand survey was conducted in 2004 and had responses from 894-902 people, depending on the question. 
'Trust' drawn from the fifth wave of the World Values Survey: This indicator is drawn from the World Values Survey question about the extent to which survey respondents believe 'most people can be trusted'. The surveys were conducted over 2004 to 2008. The New Zealand survey was conducted in 2004 and had 905 responses to the question.

Accounting standards: This indicator is drawn from an International Monetary Fund working paper. It measures the quality of accounts of leading companies in each country (De Nicolò et al. 2006).

Deaths by violence: This indicator is reported by the World Health Organization (WHO 2004). It provides the most recent estimates of age-specific rates of death by violent causes in different countries.

More details about each indicator, the criteria used for selecting the indicators, and an assessment of the quality of the data are set out in Rea (2010). Taken as a whole, the indicators measure both normative views, as well as actual behaviour. An analysis of the eight indicators suggests there is a high level of ethically motivated behaviour in New Zealand. In particular:

- compared with other countries, New Zealand has the lowest level of perceived corruption among politicians and public officials (Transparency International 2009)

- approximately 60 per cent of respondents to the New Zealand component of the fifth wave of the World Values Survey said it was never justifiable to cheat on taxes

- over 80 per cent of respondents to the New Zealand component of the fifth wave of the World Values Survey said it was never justifiable to accept a bribe

- over 70 per cent of respondents to the New Zealand component of the fifth wave of the World Values Survey said it was never justifiable to falsely claim government benefits

- slightly more than 60 per cent of respondents to the New Zealand component of the fifth wave of the World Values Survey said it was never justifiable to avoid a fare on public transport

- just over 50 per cent of respondents to the New Zealand component of the fifth wave of the World Values Survey said most people could be trusted

- the accounts of the top 10 manufacturing companies in New Zealand achieved an 83 per cent level of compliance with best practice reporting in an International Monetary Fund study that compared accounting standards across countries (De Nicolò et al. 2006) 
- the extent of criminal offending, as measured by deaths by violence, is relatively low with an average of 1.2 deaths per 100,000 from violence (WHO 2004).

How do New Zealanders compare with the citizens of other countries on these measures? Is the extent of trust and integrity 'second to none' as claimed by the 2025 Taskforce (2009). Among the sample of 26 countries, New Zealand ranks highly on many but not all measures. For example, New Zealand ranks highest in terms of the absence of perceived corruption of politicians and public servants, but only roughly average in terms of attitudes towards cheating on tax.

Figure 1 shows a simple composite index of the eight indicators to give some insight into how overall ethical behaviour might vary across the 26 nations in the sample. The index is the average of each country's ranking on each of the eight indicators. As can be seen, New Zealand scores relatively highly, but Japan and Switzerland record higher overall levels of ethical behaviour. Interestingly, Australia also scores higher than New Zealand. However, given the high level of measurement error, it is important not to place too much weight on this small difference. The index also shows a group of countries (Brazil, Mexico Malaysia, Thailand, and India) for which the overall level of ethical behaviour is low. More information on how the index was constructed is set out in Rea (2010).

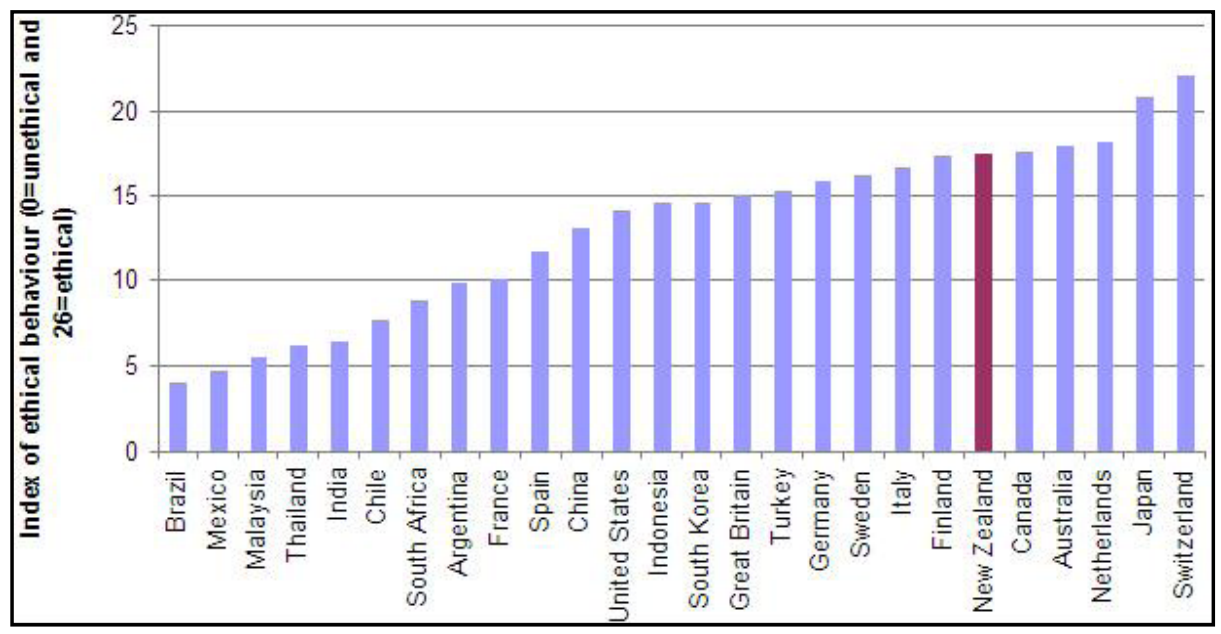

\section{Figure 1: Index of ethical behaviour across 26 selected nations}

Note: The index is the average of the rank of each country using all eight indicators. The results for China, Italy, Indonesia, and Turkey seem at odds with popular perceptions. However, they have been retained in the sample in the interests of transparency.

Source: Rea (2010). 


\section{Is ethical or trustworthy behaviour important for markets?}

In The Economics of Integrity, Anna Bernasek (2010) provides compelling evidence of the extent to which markets require integrity or ethical behaviour in order to function effectively. Bernasek's description of the workings of real world markets reveals an economy that is very different to that traditionally assumed by many economists.

The traditional economic approach generally assumes that most people are selfish. Therefore, while people might say that accepting a bribe is wrong, it is assumed most people will act unethically if they can get away with it.

The traditional approach also assumes that markets work effectively with selfish rather than ethically motivated individuals. It is assumed that penalty clauses within contracts and wider market-based reputation mechanisms mean that people generally do what they had agreed. The incentive structure of the market protects against any natural inclination towards dishonesty, duplicity, misleading claims, or poor performance.

The traditional economic approach comes to a conclusion that seems paradoxical. Despite individuals being almost pathologically self-interested and lacking in any motivation to behave in an ethical or trustworthy manner - the process of contracting within competitive markets is the best means of ensuring that people act in each other's best interest. In fact, voluntary market exchange between purely self-interested individuals is argued to provide better outcomes than exchange based on more worthy motives. This point is often made with reference to Adam Smith's ([1776] 1904, Book 1, ch. 2) famous statement:

It is not from the benevolence of the butcher, the brewer, or the baker that we expect our dinner, but from their regard to their own interest. We address ourselves, not to their humanity but to their self-love, and never talk to them of our own necessities but of their advantages.

The alluring paradox of self-interest within markets has often led economists to argue that selfish behaviour should be encouraged within markets, and even that ethical behaviour should be discouraged. However, in recent decades evidence has emerged to suggest that many of the basic assumptions of the traditional economic approach are misleading. In particular, the evidence suggests that many people behave ethically and that ethical behaviour is necessary to allow markets to operate effectively. 


\section{Are individuals selfish or ethical?}

Everyday behaviour provides compelling evidence of the prevalence of nonselfish behaviour. The existence of volunteering, charitable giving, voting, and mass collaboration projects on the internet all suggest individuals act in ways that benefit others.

'Laboratory' experiments provide evidence from more controlled conditions about the extent to which people are selfish. One of the widely replicated 'laboratory' experiments has used the ultimatum game (Güth et al. 1982). This game consists of a proposer and a responder. The proposer is given an endowment of money and the task of proposing a division of the endowment between the proposer and the responder. The responder then has two choices. They can either accept the proposed division, whereupon both parties receive what was proposed, or they can reject it, and both players receive nothing. These experiments are conducted anonymously and as one-shot encounters to isolate pure effects.

Experiments using the ultimatum game test the hypothesis that people are selfish. Where 1 per cent is the smallest possible division of the endowment, a purely selfish proposer should offer only 1 per cent of the endowment to the responder. A purely self-interested responder should also accept the 1 per cent they are offered. The evidence from experiments is that this does not occur. Most offers are between 30 per cent and 50 per cent when the game is played by university students. There is more diversity of offers when the experiments are conducted among people from small-scale, less-developed societies. Where offers are low, responders tend to reject offers. For example, about half the time offers less than 20 per cent are rejected (Camerer and Fehr 2004).

Other experimental games provide evidence about the extent of selfish behaviour. Another widely replicated experiment uses the structure of the public goods game (Ledyard 1995). In this experiment, participants can choose to contribute their endowment to a public good or free-ride on the contributions of others. The hypothesis that all individuals are selfish is rejected in experiments based on one-shot public goods games. Instead of free-riding on others, players typically contribute 50 per cent of their endowment to the public good (Carmerer and Fehr 2004).

There is also good evidence from field experiments about the extent to which people are selfish. In natural experiments such as those that occur with anonymous giving, there is considerable evidence that a proportion of people do not behave strictly selfishly (Frey and Meier 2004; List 2004; DellaVigna 2009). 
Overall, the evidence suggests that many people behave in a non-selfish manner. However, the experiments also reveal considerable heterogeneity. Most experiments find that a minority of people are consistently selfish. The size of this minority differs when experiments are repeated in different communities (Gintis et al. 2005).

One possible reason for non-selfish behaviour might be that people care about others. Another possible reason might be that people have preferences to do 'the right thing'. While the evidence seems to be that both forms of social preferences exist, behaviour based on doing what is right seems to be an important motivation. The finding that many people expect others to behave fairly, and that many people are willing to invest resources in punishing those who do not behave fairly, seems to suggest that norms of ethical behaviour play an important role (Bicchieri 2006).

As an aside, it is interesting to note that the recent findings about selfish behaviour have also led to a more careful interpretation of Adam Smith's work. As well as the Wealth of Nations (1776), Smith also wrote The Theory of Moral Sentiments (1759). In that later work, Smith argued that people have a natural sympathy towards others. Smith argued that this natural sympathy led to the motivation of benevolence. A careful reading of the famous quotation about buying dinner (above) shows that Smith was contrasting 'benevolence' with 'self-interest' (Alvey 1999).

\section{Do markets require selfish behaviour?}

In direct contrast to the traditional economic assumption, recent evidence suggests that selfish behaviour is actually a problem in real world markets.

Selfish behaviour is not a problem in the traditional economic approach because it is assumed there are no transactions costs. It is assumed individuals are fully rational and have perfect information, and no costs are associated with writing, monitoring, or enforcing contracts. However, studies of the actual nature of market exchange show that transactions costs are very important, and individuals invest significant resources in the process of contracting (Williamson 1985).

In the real world of transactions costs, selfish behaviour or 'opportunism' becomes a problem. Classic examples of markets where this occurs include:

- the markets for used vehicles where the costs of determining quality leads to some sellers representing 'lemons' as good quality cars (Akerlof 1970)

- the employment of chief executives where contracts are incompletely specified and there are costs to the company of terminating a contract (in 
these instances shareholders need to trust that the company manager is going to act reasonably in the performance of their duties) (Williamson 1985)

- insurance markets where monitoring costs create a risk of moral hazard (Arrow 1963).

A key finding is that markets sometimes fail or function poorly because of selfish behaviour. As a result, individuals spend a great deal of time constructing governance arrangements to reduce their risks from selfish behaviour. In some instances, they completely avoid transactions where the probable costs of selfish behaviour are high.

New Institutional Economics identifies three stages in the contracting process: search and screening, the specification of contracts, and monitoring and enforcement. Each stage has the same structure. At each stage, the parties face some level of uncertainty. Where a transaction requires the parties to invest significant resources in overcoming uncertainty, it is often not economic to completely undertake that stage of the contracting process. This then leaves the parties open to the risk of losses from selfish behaviour.

Consider for example the first stage of contracting - search and screening. Many transactions are conducted despite search and screening activities being incompletely performed. As a result, there is residual uncertainty about quality, and parties face a risk of adverse selection - a risk that the quality of products or services may turn out to be less than promised or expected.

There is a similar problem when writing contracts. The process of writing and specifying contracts is also often incompletely performed. This tends to occur where there are complex or long-term transactions. Because of incomplete specification, parties are exposed to a risk of losses from selfish behaviour. This occurs where one party attempts to amend an incomplete contract in a manner that 'unfairly' changes the distribution of the surplus from the exchange. In short-term incomplete contracts - such as contracts involving medical professionals and their patients - therez is a risk of opportunistic behaviour because one party needs to trust the other to determine some of the details of the contract. In longer-term relational contracts, the risk of opportunism is referred to as 'hold up'. This occurs where one party attempts to force an unfair amendment to an incomplete contract where there are sunk costs (Williamson 1985).

Where monitoring and enforcement of contracts is costly, these activities also tend to be incompletely performed. In this instance, parties are exposed to the risk of selfish behaviour in the form of contractual non-performance or moral hazard. For example, where it is difficult to observe agreed performance, one party runs the risk that the other will not fulfil their side of the bargain. 
When faced with the risk of opportunism arising from incompleteness, parties to contracts can create contractual governance arrangements called safeguards. These are protections against the risk of selfish behaviour or opportunism. Safeguards may include writing more detailed provisions such as guarantees (for example, where parties are exposed to the risk of adverse selection); creating self-enforcing mechanisms through the use of bonds (for example, where parties are exposed to the risk of hold up); contracting only with individuals who have a good reputation (for example, where there is a risk of moral hazard); structuring repeated interactions, so that selfish behaviour in one instance can be punished in a subsequent trade; or trading only with family and friends who are less likely to be opportunistic. Critically, the construction of contractual safeguards is costly and not always fail-safe.

\section{Role of ethical or trustworthy behaviour in markets}

Contracting is a costly process and often undertaken in an incomplete manner. As a result, market participants frequently need to trust that others will act in a trustworthy or ethical manner.

This can work well where most individuals are ethical and trustworthy. In such an environment, parties to contracts do not have to invest much in ensuring that every stage of the contracting process is complete, and they do not have to invest as much in creating safeguards against opportunism. They are also more likely to undertake risky transactions.

However, this approach becomes difficult where only a small proportion of individuals are ethical or trustworthy. Individuals will avoid risky transactions, and those that are undertaken will require costly investments in governance to protect against cheating and other forms of opportunism.

It is easy to identify examples of what occurs in markets where ethical behaviour becomes less prevalent. Consider, for example, car and appliance repair where purchasers find it difficult to verify the quality of work. If a large proportion of firms are ethical and trustworthy, then the overall costs and risks of purchasing repairs will be low. However, if there is a large proportion of 'dodgy' firms, then consumers will have higher search costs, they will spend more time negotiating detailed contracts, and they will probably incur higher costs in disputes about defective repairs. Competition within the market will also be hindered, as individuals will want to remain with the firm they know.

It is important to note that where there are significant transactions costs, unethical behaviour can be tolerated or even encouraged by the incentive structure of the market. Where there is considerable uncertainty and a large proportion of untrustworthy participants, the market will function poorly or 
even fail completely. In this case, a version of Gresham's law can apply as 'bad companies drive out the good'. In such an environment, the market becomes dominated by selfish rather than ethical participants.

Consider as an example the market for non-bank savings. A saver in this market faces an adverse selection problem because of uncertainty about the risks of investing. Finance companies in the market may differ in the extent to which they inform potential customers of the risks associated with their products. Some companies might, in the interests of higher profits, fail to fully disclose the risks in their balance sheet. Other companies might be of the view that it is ethical to fully disclose such risks. In some circumstances, finance companies that are more ethical will find it hard to compete against firms with lower standards. If the industry becomes dominated by unethical firms, then savers will, in the end, save less because they face a market that offers only poor-quality, risky products. Conversely, if ethical behaviour is widespread, then this allows an efficient market. Savers are not surprised by unexpected losses, there is less need to invest in due diligence, and savers will save more.

\section{Ethical behaviour where markets fail}

As well as providing an important foundation for markets to operate effectively, ethical or trustworthy behaviour is important for another important economic reason. Because of transactions costs, not everything is traded in markets, and ethical behaviour is an important means of allocation where markets fail or work imperfectly. Where there are externalities, public goods, or common pool resources ethical behaviour often provides an important means of regulating behaviour. Doing what is 'right' is important in circumstances such as recreational fishing, driving in a car, or polluting the atmosphere (Ostrom 2000).

\section{Is there any evidence to suggest a link between ethical behaviour and New Zealand's economic performance?}

The theory suggests ethical behaviour is important for the economy, because it both reduces the costs of contracting and provides a means of guiding behaviour when markets are absent. However, although the theory is persuasive, the critical question is whether there is any empirical evidence to support or refute the notion that ethics are important for economic performance. 
To assess whether ethical behaviour plays a meaningful role in economic growth, it is possible to use the variation in ethics between countries. Countries that have higher ethical standards should, other things being equal, have higher growth rates and higher levels of per capita economic output.

Zak and Knack (2001) looked at this question using the 'trust' indicator. They analysed growth and investment rates in 41 countries over 1970 to 1992, and found that the level of reported trust in a country had an important influence over the level of growth and investment. Zak and Knack found that after controlling for a variety of other influences on growth, a 15 percentage point increase in the level of reported trust raised the level of annual economic growth in a country by 1 per cent per year.

A less sophisticated approach is to look at the relationship between gross domestic product per capita and the index of ethical behaviour described previously. This is shown graphically in Figure 2. As can be seen, a reasonable correlation exists between a country's ethical ranking and gross domestic product per capita. Countries with high levels of ethics tend to be richer, and those with lower levels of ethics tend to be poorer

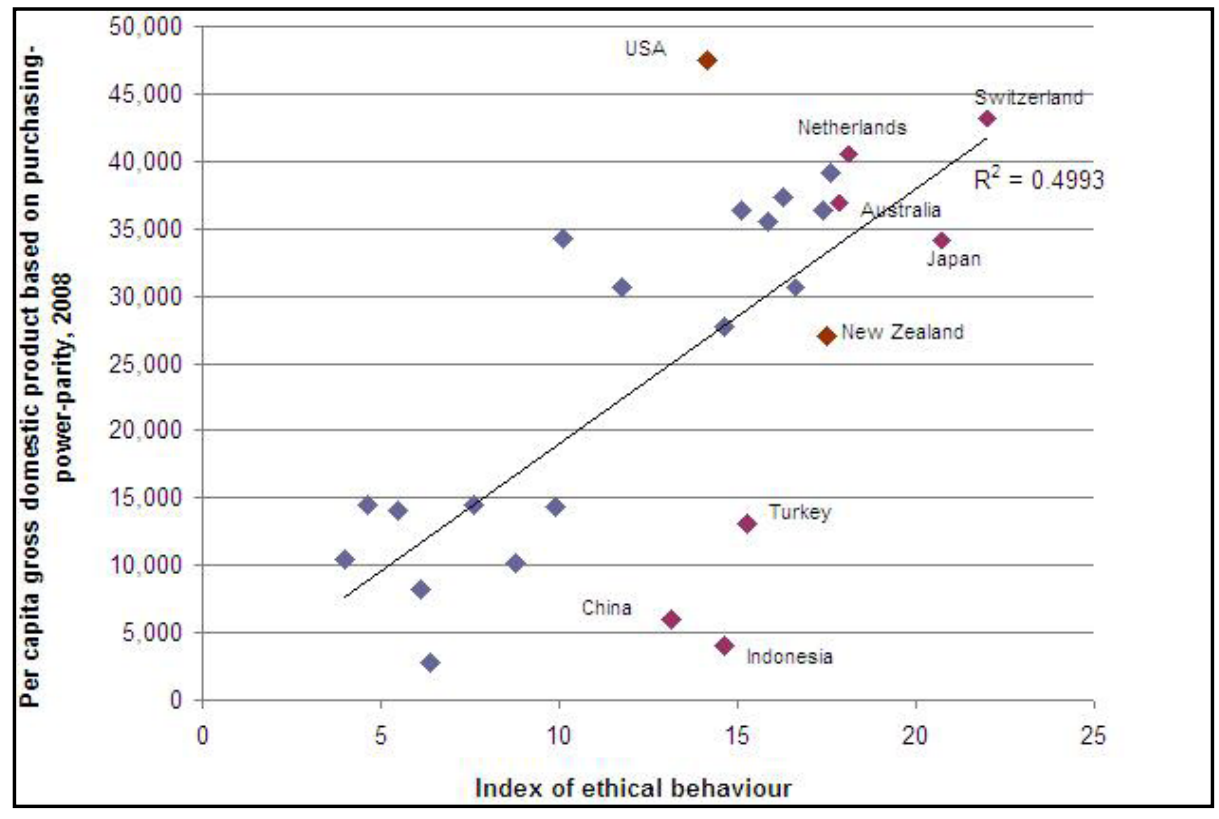

Figure 2: Index of ethical behaviour and gross domestic product per capita across 26 selected nations

Note: The index of ethical behaviour is the average of each country's ranking on eight indicators of ethics. Source: Gross domestic product per capita data is from IMF (2003b), otherwise Rea (2010). 
Of course, the correlation may be a statistical artefact. Gross domestic product per capita is influenced by many factors, and it might be that not controlling for these other influences gives rise to a false relationship where some of these other factors are correlated with ethical behaviour. The evidence suggests that good institutions - well-defined and enforceable property rights, effective and fair justice systems, and controls over public corruption are critically important for economic growth (Acemoglu and Johnson 2005; Glaeser et al. 2004; IMF 2003a; World Bank 2001). It is possible that these institutions also engender a high level of ethical behaviour, and so give rise to a spurious relationship between economic output and ethical behaviour.

It could also be that there is a causal relationship, but occurring in a reverse direction. It is possible that higher levels of economic output create higher levels of ethical behaviour. This is a proposition advanced by Adam Smith. In his lectures on jurisprudence, Smith (1762, p. 458) argued:

Whenever commerce is introduced into any country, probity and punctuality always accompany it. These virtues in a rude and barbarous country are almost unknown. Of all the nations in Europe, the Dutch, the most commercial, are the most faithfull to their word. The English are more so than the Scotch, but much inferiour to the Dutch, and in the remote parts of this country they [are] far less so than in the commercial parts of it. This is not at all to be imputed to national character, as some pretend. There is no natural reason why an Englishman or a Scotchman should not be as punctual in performing agreements as a Dutchman. It is far more reduceable to self interest, that general principle which regulates the actions of every man, and which leads men to act in a certain manner from views of advantage, and is as deeply implanted in an Englishman as a Dutchman. A dealer is afraid of losing his character, and is scrupulous in observing every engagement. When a person makes perhaps 20 contracts in a day, he cannot gain so much by endeavouring to impose on his neighbours, as the very appearance of a cheat would make him lose.

Smith argued that commerce increased the prevalence of ethical behaviour because there were incentives to behave ethically. However, this view, while undoubtedly containing some element of truth, crucially depends on the nature of the markets in question. Where ethical conduct is highly visible, market incentives will encourage ethical behaviour. However, where markets are characterised by uncertainty and it is hard to detect cheating, then the strong incentives of the market may in fact encourage unethical conduct.

It is also possible that the observed correlation between ethics and economic output in Figure 2 occurs because of a causal relationship from ethics to economic performance. If this were the case, it would mean New Zealand - despite already having a relatively high ranking - might be able to reach the income levels of Australia if we had levels of ethical behaviour similar to Switzerland. 
The empirical question about the relationship between ethical standards and economic performance can also be assessed in other ways. One approach is to look at particular industries. If there is a causal relationship between higher levels of ethical behaviour and economic performance, then it should be relatively easy to point to examples where ethics and integrity play an important role in the effective working of a market. Bernasek (2010) provides several such case studies. Conversely, it should also be possible to point to industries where poor ethical standards have adversely affected particular industries. Table 1 presents brief examples of industries where ethical standards seem to have been a problem. The table attempts to identify the nature of the failing in ethical standards, and the scale and economic consequences of the failure.

Table 1: Impact of ethical standards on particular industries in New Zealand

\begin{tabular}{|c|c|c|}
\hline Example & $\begin{array}{l}\text { Nature of the failure of ethical } \\
\text { standards }\end{array}$ & $\begin{array}{l}\text { Potential scale of } \\
\text { issue }\end{array}$ \\
\hline $\begin{array}{l}\text { Collapse of } \\
\text { the finance } \\
\text { company } \\
\text { sector, } \\
\text { 2004-09 }\end{array}$ & $\begin{array}{l}\text { About } 27 \text { finance company failed between } 2006 \\
\text { and } 2008 \text {. The Registrar of Companies reported } \\
\text { 'that a number of the failed finance companies } \\
\text { were in the end acting in a similar manner to } \\
\text { ponzi schemes'. }{ }^{1} \text { Many firms misled investors } \\
\text { about the performance of loans, and some } \\
\text { auditors failed in their duty to issue qualified } \\
\text { audits. }\end{array}$ & $\begin{array}{l}\text { The Reserve Bank of } \\
\text { New Zealand estimated that } \\
\text { the direct loss to creditors } \\
\text { of the finance companies } \\
\text { in receivership at that time } \\
\text { ranged from } \$ 0.6 \text { billion to } \\
\$ 1 \text { billion. }^{2}\end{array}$ \\
\hline $\begin{array}{l}\text { Inv } \\
\text { ad }\end{array}$ & $\begin{array}{l}\text { Evidence of poor information disclosure, } \\
\text { poor training and management of advisors, } \\
\text { inappropriate selling practices, and perverse } \\
\text { incentive payments. }^{3}\end{array}$ & $\begin{array}{l}\text { In } 2001, \text { there were } 7,836 \\
\text { 'financial advisers', } 2,817 \\
\text { 'financial dealers or brokers' } \\
\text { and } 3,840 \text { 'insurance } \\
\text { representatives'. }{ }^{4}\end{array}$ \\
\hline Lea & $\begin{array}{l}\text { The Hunn Report suggests that one of the } \\
\text { reasons for the construction of leaky homes was } \\
\text { a lack of care and responsibility in the design, } \\
\text { construction, and certification of buildings } \\
\text { following the repeal of the Building Act. }{ }^{5} \text { This } \\
\text { seems to have been particularly prevalent in } \\
\text { developer driven construction projects. }\end{array}$ & $\begin{array}{l}\text { The Hunn Report suggested } \\
\text { the costs of repairing } \\
\text { leaky homes would be } \\
\text { between } \$ 0.12 \text { billion and } \\
\$ 0.24 \text { billion. More recent } \\
\text { reports are suggesting } \\
\$ 11.5 \text { billion. }^{6}\end{array}$ \\
\hline $\begin{array}{l}\text { Tax avoidance } \\
\text { by major } \\
\text { banks using } \\
\text { structured } \\
\text { finance } \\
\text { transactions }\end{array}$ & $\begin{array}{l}\text { Over the last decade several banks used } \\
\text { structured finance transactions to minimise their } \\
\text { tax liabilities. The High Court found that the } \\
\text { BNZ and Westpac's use of these transactions } \\
\text { constituted illegal tax avoidance. }{ }^{7} \text { These cases } \\
\text { represent unethical behaviour in that the } \\
\text { banks took advantage of legal uncertainty and } \\
\text { aggressively minimised their tax liabilities, rather } \\
\text { than complying with the intent of the legislation. }\end{array}$ & $\begin{array}{l}\text { Treasury provisioned } \\
\$ 1.4 \text { billion of income in the } \\
\text { financial year to } 30 \text { June } \\
2009 \text { to represent lost } \\
\text { tax revenue. The Inland } \\
\text { Revenue Department } \\
\text { has invested significant } \\
\text { resources in prosecuting the } \\
\text { cases so far. }\end{array}$ \\
\hline
\end{tabular}

Sources: (1) Harris (2009, p. 10). (2) RBNZ (2008). (3) Consumer (2009); Grimes (2005); Securities Commission (2002). (4) MED (2007). (5) Hunn et al. (2002); Parliamentary Library (2002). (6) Hunn et al. (2002); NZPA (2009). (7) BNZ Investments Ltd v. Commissioner of Inland Revenue 15 July 2009, Wild J, HC Wellington CIV 2004-485-1059; Westpac Banking Corp. v. Commissioner of Inland Revenue 7 October 2009, Harrison J, HC Auckland CIV 2005-404-2843. (8) Treasury (2009). 
The collapse of finance companies, the related problem with financial advisers, the widespread construction of leaky buildings, and tax avoidance by major banks all point to the relationship between ethical standards and economic performance.

In a similar manner, the global financial crisis also provides insights into the relationship between ethical standards and economic performance. One view is that an important cause of the global financial crisis was a failure of ethics and integrity within large multinational financial institutions. This point was made succinctly in early 2009 by the secretary-general of the OECD when he stated (Gurría 2009):

The current global economic crisis is costing the world trillions of dollars, a protracted recession, millions of lost jobs, a huge loss of confidence in financial markets and a reversal in our efforts to cure global poverty. It is the result of the combination of several failures. A failure of business ethics is one of them; one that lies at the epicenter of this financial and economic earthquake.

Business ethics should be at the center of any new road-map for the global economy. Markets should not only be more stable, but morally acceptable as well. It is time to reunite ethics and economics.

Similar sentiments were also expressed by the chair of New Zealand's Securities Commission (Diplock 2009):

There is no question in my mind that a major factor precipitating the global crisis was the eventual overwhelming by unregulated market forces of traditional, centuries-old standards of conduct.

We are now transitioning from a time when ethics in business - at any level - tended to be seen more as an optional add-on than an essential operating principle.

Lack of ethical standards varied from illegal fraud (as in the case of Bernie Madoff) to the selling of mortgages to individuals who could not afford them to the misleading ratings of the resulting bundles of mortgages by ratings agencies. An important cause of the erosion of traditional prudential standards seems to have been payment systems that provided incentives for behaviour that was at variance to traditional standards of behaviour (Blinder 2010). If this analysis is correct, it provides a significant example of the importance of ethical standards for the operation of markets. 
Therefore, returning to the overall question, it does appears there is reasonable evidence of a causal relationship between levels of ethical behaviour and overall economic performance. This evidence arises when comparing countries, as well as when looking more closely at the performance of particular industries.

\section{How should public policy support ethical behaviour?}

Theory and evidence suggest ethical behaviour plays an important role in allowing markets to operate effectively. However, despite this evidence, ethical or trustworthy behaviour is not a major focus of economic policy in New Zealand. The Treasury's (2008) post-election briefing on medium-term economic policy makes no mention of ethics, and among academic and private sector economists there is little research on ethics and economic growth. ${ }^{1}$

One reason for this lack of focus seems to be the view that New Zealand already has a high degree of ethical and trustworthy behaviour. The evidence in this paper suggests that the level of ethical and trustworthy behaviour, although high, is not as high as in some other countries, and across many indicators there is, of course, room for improvement.

Another reason for a lack of focus is the view that while trust and integrity might be important, the government cannot directly influence such behaviour. Instead, it is argued that the best means of fostering ethical or trustworthy behaviour is to deregulate markets. Competitive markets are assumed to punish cheating, so removing barriers to competition is often argued to be the only route to a more trustworthy and ethical economy. Market-based mechanisms - including contractual guarantees, reputation effects, and the internalisation of risky transactions within firms - are argued to be the best means by which ethical behaviour can be encouraged. By way of contrast, it is argued that attempts by the government to require people to be ethical or trustworthy will tend to backfire because of poor information or incentives.

The typical view of economic policy makers in New Zealand is that the government does not have the ability to regulate for ethical or trustworthy behaviour with any 'delicacy' or 'judgement'. However, an alternative view recognises the importance of clear legal rights and competitive markets, but points out that there are particular areas in which the government can improve the level of ethics, trust, and integrity. In this wider pro-ethical approach to market regulation, it is argued that in some areas (such as education), the

1 Murray Petrie's work on social norms and institutions is an important exception to this (Petrie 2002). 
government can influence the extent to which economic actors are motivated to behave in an ethical manner. It is also argued that in some markets - where there is very high uncertainty and high costs of unethical behaviour - direct government regulation should be used to avoid the sometime significant consequences of unethical behaviour. In the discussion that follows, I look at specific elements of this wider pro-ethical approach.

\section{Legal regulation}

In all countries, legal rules are used to require or encourage ethical or trustworthy behaviour in particular circumstances. For example, many countries have legal rules that ban the sale of certain dangerous goods, outlaw deceptive advertising, or impose fiduciary requirements in certain contracts.

Importantly, as with all legal regulation, these restrictions can come in different forms. One dimension is that the legal rules may be mandatory or default provisions. Defaults can be contracted out of, but encourage ethical behaviour because they establish good behaviour as the norm. Mandatory provisions on the other hand cannot be contracted out of, and are often argued for when there are particularly significant risks such as death (for example, vehicle safety standards).

A further dimension of legal regulation is that rules can be specific (for example, you cannot sell fireworks to people aged under 18) or constructed as general duties (for example, sellers owe a duty of care to consumers). The advantage of general duties is that they are flexible and respond to changing circumstances. However, the trade-off is that they also create a degree of legal uncertainty.

From an economic policy perspective, the question is whether legislative restrictions on economic freedom aimed at improving ethical or trustworthy behaviour will enhance the functioning of markets. One circumstance where, on the face of it, it might appear possible, is in a particular market characterised by a high level of uncertainty and where the consequences of unethical or untrustworthy behaviour are significant.

For example, where the quality of a good or service is difficult to determine and dangerous, it is often argued that statutory safety regulation will lower the costs of trading and ensure fewer consumers are harmed. The general law of negligence and specific product regulation (such as around the sale of alcohol or cigarettes to children) are common examples.

A further example is the laws governing a relationship of trust where the risk and consequences of unethical behaviour are significant. Fiduciary duties create requirements for ethical conduct in contracts where one party has to rely on 
another to act in good faith. In this area, statutory requirements may also be more specific. As well as general fiduciary duties, some countries have specific bans on self-dealing and related-lending by directors and senior managers (Djankov et al. 2008; La Porta et al. 2003).

\section{Quasi-legal and informal regulation}

It is also common to observe quasi-legal rules aimed at promoting ethical or trustworthy behaviour within markets. One example is occupational selfregulation. As part of the training in some traditional apprenticeships (for example, doctors, plumbers, hairdressers, carpenters, and lawyers) an emphasis is on ensuring apprentices learn standards that are the professions rules about ethical conduct. In many occupations there are also written codes of behaviour that define and promote ethical behaviour. Such quasi-legal and informal regulation helps to guarantee a minimum level of quality within these markets.

\section{Social norms}

The prevalence of ethical or trustworthy behaviour also depends on social norms and culture. The role of these is well recognised within firms. For example, an important issue for firms is creating a workplace culture that minimises fraud. Other workplace standards (for example, hygiene practices in fast-food outlets) can also be viewed as attempts by firms to create norms about ethical behaviour.

Bicchieri (2006) is of the view that social norms are a collection of rules, preferences to follow rules, and expectations. A key feature of these norms is the general expectation that they ought to be followed, but this is conditional on other people also following these norms. Ethical social norms will be effective where principles of ethical conduct are clearly articulated, where behaviour is transparent, and where people can be informally punished (Harms and Skyrms 2008).

There is increasing evidence that social norms can be influenced (Cialdini 2006). One way is though the use of descriptive norms (informing people of what others are doing) and another through injunctive norms (identifying the ethical course of action).

To test the notion that ethical behaviour might be open to influence about 'descriptive norms', I recently conducted a small experiment with a class of public policy students. The experiment involved randomly assigning students to two groups, and asking the students (in individual questionnaires) to identify how they would behave when confronted by five different ethical dilemmas. 
The ethical dilemmas were identical for both groups, except for a small amount of information in each question about how other people behaved. For example, one of the ethical dilemmas was expressed as follows in the two questionnaires:

A very small number of tertiary students use accounting firms to file their tax returns. They do this to access a soon to be closed legal loophole that gives them a refund of $\$ 1000$ on their student fees. Would you pay $\$ 40$ to an accounting firm to access this refund?

Almost all tertiary students use accounting firms to file their tax returns. They do this to access a soon to be closed legal loophole that gives them a refund of $\$ 1000$ on their student fees. Would you pay $\$ 40$ to an accounting firm to access this refund?

It appears that information about the behaviour of other people affected how students responded to the ethical dilemma questions. The group that was told other people behaved in an ethical fashion indicated that they would make ethical choices 58 per cent of the time. The group that was told people behaved unethically made ethical choices only 38 per cent of the time. Although a small sample $(n=28)$, the difference was statistically significant. See Rea (2010) for more detail on the nature of this experiment.

The finding that behaviour is influenced by descriptive norms about the behaviour of others has also been found in a variety of field and laboratory experiments. In a famous early experiment, individuals seeing other people place rubbish in a bin reduced the likelihood of littering (Cialdini et al. 1990). The statement that 'other people reuse their towels' also seems to be a very effective means of ensuring guests in hotels reuse their towels (Cialdini, 2006).

To some extent, it seems that social norms are amenable to influence by the government. Examples where there seems to have been some success include smoking, the payment of tax, the use of condoms, recreational fishing limits, littering, safe driving, and domestic violence. Another public policy implication is that ethical leadership - a clear articulation and modelling of ethical standards - is important for maintaining social norms of integrity.

\section{Socialisation and education}

Another important area of public policy to consider relates to the education and socialisation of children and young people.

The evidence seems to suggest that ethical behaviour is apparent very early in a child's life and progressively develops. Crucially, ethical behaviour seems influenced by early environments. Traditionally, a focus of the study of moral development was an analysis of moral reasoning. However, it now appears that 
other factors such as personality are also very important. The formation of ethical dispositions in children and young people focuses attention on the role of early childhood experiences, parenting, and schooling (Killen and Smetana 2006; Narvaez and Lapsley 2009). Parenting programmes, early intervention programmes, and civics education and experiences for young people seem important to foster ethical behaviour.

\section{Transparency mechanisms}

Lastly, mechanisms that promote transparency of behaviour are also important for fostering ethical and trustworthy behaviour. Consumer organisations and investigative reporting play an important role in exposing organisations that act unethically. Mandating public reporting of behaviour (for example, requiring corporate disclosure of a company code of ethics) is another means by which the government can encourage ethical or trustworthy behaviour.

\section{Conclusion}

Traditionally, economists have not worried about unethical or untrustworthy behaviour. It was assumed that even though individuals were almost entirely selfish, market incentives would punish cheating and untrustworthy behaviour.

However, recent evidence suggests quite a different conclusion. First, people are not as self-seeking or selfish as traditionally assumed. Second, markets need people to act with a degree of trust and integrity. The existence of transaction costs means contracting within markets is a costly and difficult exercise, and in most markets trust is needed.

Without high levels of ethical behaviour, the costs and risks of contracting are greatly increased. In markets where ethical behaviour is absent, some risky transactions will be avoided, and individuals and firms will waste considerable time and resources on the process of contracting.

It is highly likely that the general prevalence of ethical behaviour is an important influence over a country's overall economic performance. A comparison of the relative economic prosperity of different nations shows a positive relationship between indicators of ethics and economic output. It is also not hard to find examples of industries in New Zealand where poor ethical standards have had adverse economic consequences.

The relationship between ethical behaviour and economic performance means that economists have to carefully examine their policy prescriptions. There is some evidence that ethical behaviour can be influenced positively by public 
policy. At times, this might involve increased legal regulation to ban particular unethical practices, as well as a more general focus on encouraging a climate of ethical behaviour.

Ethical behaviour should also be an important focus of New Zealand's economic policy agenda because it represents an area where the country potentially has a comparative advantage. Indicators suggest that New Zealand, although not the highest, is a good performer compared with many other countries in terms of measured ethical behaviour. In future decades, our rankings in this area should make New Zealand an attractive destination for investment, if our regulatory regime can adequately foster ethical and trustworthy behaviour.

\section{References}

Acemoglu, D., and S. Johnson. 2005 'Unbundling institutions.' Journal of Political Economy 113(5): 949-95.

Akerlof, A. 1970. 'The market for "lemons": Quality uncertainty and the market mechanism.' Quarterly Journal of Economics 84(3): 488-500.

Alvey, J. 1999. An Introduction to Economics as a Moral Science. Working paper 15. Independent Institute. www.independent.org/pdf/working_papers/15_ introduction.pdf (accessed 13 November 2009).

Arrow, K. 1963. 'Uncertainty and the welfare economics of medical care.' American Economic Review 53(5): 941-73.

Bernasek, A. 2010. The Economics of Integrity. New York: Harperstudio.

Bicchieri, C. 2006. The Grammar of Society: The nature and dynamics of social norms. Cambridge: Cambridge University Press.

Blinder, A. 2010. 'When greed is not good.' Wall Street Journal, 11 January. www://online.wsj.com/article/SB10001424052748703652104574652242436 408008.html.

BNZ Investments Ltd v. Commissioner of Inland Revenue 15 July 2009, Wild J, HC Wellington CIV 2004-485-1059. http://jdo.justice.govt.nz/jdo.

Camerer, C., and E. Fehr. 2004. 'Measuring social norms and preferences using experimental games: A guide for social scientists.' In J. Henrich, E. Fehr, and H. Gintis (eds). Foundations of Human Sociality: Economic experiments and ethnographic evidence from fifteen small-scale societies. Oxford: Oxford University Press. 
Cialdini, R. 2006. Influence: The psychology of persuasion Rev. edn. New York: Harper Paperbacks.

Cialdini, R., R. Reno, and C. Kallgren. 1990. 'A focus theory of normative conduct: Recycling the concept of norms to reduce littering in public places.' Journal of Personality and Social Psychology 58: 1015-26.

Consumer. 2009. 'Financial advisers: Getting good advice.' www.consumer.org. nz/reports/financial-advisers/getting-good-advice (accessed 25 February 2010).

De Nicolò, G., L. Laeven, and K. Ueda. 2006. Corporate Governance Quality: Trends and real effects. Working paper WP/06/293. International Monetary Fund. www.imf.org/external/pubs/ft/wp/2006/wp06293.pdf.

DellaVigna, S. 2009. 'Psychology and economics: Evidence from the field.' Journal of Economic Literature 47(2): 315-72.

Diplock, J. 2009. 'The financial crisis and corporate governance.' Speech to Auckland Rotary. www.seccom.govt.nz/speeches/2009/220609.shtml.

Djankov, D., D. La Porta, F. López-de-Silanes, et al. 2008. 'The law and economics of self-dealing.' Journal of Financial Economics 88(3): 430-65.

Frey, B. S., and S. Meier. 2004. 'Social comparisons and pro-social behavior: Testing "conditional cooperation" in a field experiment.' American Economic Review 94(5): 1717-22.

Gintis, H., S. Bowles, R. Boyd, et al. 2005. Moral Sentiments and Material Interests: The foundations of cooperation in economic life. Cambridge MA: MIT Press.

Glaeser, E., R. La Porta, F. López-de-Silanes, et al. 2004. 'Do institutions cause growth?' Journal of Economic Growth 9(3): 271-303.

Grimes, A. 2005. 'Improving consumer trust in the retail savings industry.' Paper prepared for the Retirement Commission. www.retirement.org.nz/ files/retirement-files/research-library/improving-consumer-trust-in-theretail-savings-industry.pdf.

Gurría, A. 2009. 'Business ethics and OECD principles: What can be done to avoid another crisis?' Remarks by OECD secretary-general at the European Business Ethics Forum, Paris, 22 January 2009. www.oecd.org/document/3/ 0,3343,en_2649_201185_42033219_1_1_1_1,00.html. 
Güth, W., R. Schmittberger, and B. Schwarze. 1982. 'An experimental analysis of ultimatum bargaining.' Journal of Economic Behavior and Organization 3(4): 367-88.

Harms, W., and B. Skyrms. 2008. 'Evolution of moral norms.' In M. Ruse (ed.). The Oxford Handbook of Philosophy of Biology. Oxford: Oxford University Press, ch. 18.

Harris, N. 2009. 'Finance company failures: Observations of the Registrar of Companies.' In Commerce Committee. 2007/08 Financial review of the Ministry of Economic Development: Report of the Commerce Committee. Wellington: Ministry of Economic Development, Appendix B. www.parliament.nz/ NR/rdonlyres/16F22058-8DD8-4541-B9A9-064848076239/100892/DBSCH_ SCR_4272_6521.pdf.

Hunn, D., I. Bond, and D. Kernohan. 2002. Report of the Overview Group on the Weathertightness of Buildings to the Building Industry Authority. Wellington: Building Industry Authority. www.dbh.govt.nz/whrs-publications-reports.

IMF. 2003a. 'Growth and institutions.' In World Economic Outlook: April 2003. Washington: International Monetary Fund, ch. 3. www.imf.org/external/ pubs/ft/weo/2003/01.

IMF. 2003b. The World Economic Outlook (WEO) Database April 2003. Washington: International Monetary Fund. www.imf.org/external/pubs/ft/ weo/2003/01/data/index.htm (acessed October 2009).

Killen, M., and J. Smetana. 2006. Handbook of Moral Development. New Jersey: Lawrence Erlbaum Associates.

La Porta, R., F. López-de-Silanes, and G. Zamarripa. 2003. 'Related lending.' Quarterly Journal of Economics 118(1): 231-68.

Ledyard, J. 1995. 'Public goods: A survey of experimental research.' In J. Kagel and A. E. Roth (eds). Handbook of Experimental Economics. Princeton: Princeton University Press.

List, J. 2004, 'Young, selfish and male: Field evidence of social preferences.' Economic Journal 114(492): 121-49.

MED. 2007. Financial Advisers: A new regulatory framework. Regulatory Impact Statement. Wellington: Ministry of Economic Development. www.med.govt. nz/upload/47854/financial-advisors-ris.pdf.

Narvaez, M., and D. Lapsley. 2009. Personality, Identity and Character: Explorations in moral psychology. Cambridge: Cambridge University Press. 
Public Policy: Why ethics matters

NZPA (New Zealand Press Association). 2009. 'Leaky homes bill likely to top \$11.5 billion.' NZ Herald, 18 August. www.nzherald.co.nz/nz/news/article. cfm?c_id=1\&objectid $=10591520$.

Ostrom, E. 2000. 'Collective action and the evolution of social norms.' Journal of Economic Perspectives 14(3): 137-58.

Parliamentary Library 2002. 'Leaky buildings.' Background Note 2002/10, 6 November. www.parliament.nz/NR/rdonlyres/464AB9F9-B197-4B53BE9F-4F411CB67877/360/0210LeakyBuildings1.pdf.

Petrie, M. 2002. Institutions, Social Norms and Well-Being. Working paper 02/12. Wellington: The Treasury. www.treasury.govt.nz/publications/researchpolicy/wp/2002/02-12.

RBNZ. 2008. Financial Stability Report. Wellington: Reserve Bank of New Zealand. www.rbnz.govt.nz/finstab/fsreport/3311557.pdf.

Rea, D. 2010. Would New Zealand's Economic Performance Improve if We Were More Ethical? Working paper 10/05. Wellington: Institute of Policy Studies, School of Government, Victoria University of Wellington. http://ips.ac.nz/ publications/publications/list/7.

Securities Commission. 2002. Investment Advisers: A case study. Gideon Investments Pty Limited - Morison Guildford \& Associates Limited. www.seccom.govt.nz/publications/documents/morison_guildford/index.shtml.

Smith, A. [1759] 1790. The Theory of Moral Sentiments. 6th edn. London: A. Millar. Available from the Library of Economics and Liberty, www. econlib.org (accessed 1 November 2009).

Smith, A. 1762. 'Lectures on jurisprudence'. In R. L. Meek, D. D. Raphael, and P. G. Stein (eds). 1982. The Glasgow Edition of the Works and Correspondence of Adam Smith. Vol. 5. Indianapolis: Liberty Fund.

Smith, A. 1776. An Inquiry into the Nature and Causes of the Wealth of Nations. 5th edn. Edited by E. Cannan. 1904. London: Methuen. Available from the Library of Economics and Liberty, www.econlib.org/library/Smith/smWN. html (accessed 17 October 2009).

Transparency International. 2009. Corruption Perceptions Index 2008. www. transparency.org/policy_research/surveys_indices/cpi (accessed 24 October 2009).

Treasury. 2008. Briefing to the Incoming Minister of Finance: Medium-term economic challenges. Wellington: The Treasury. www.treasury.govt.nz/ publications/briefings/2008/big08.pdf. 
Treasury. 2009. Financial Statements of the Government of New Zealand for the Year Ended 30 June 2009. Wellington: The Treasury. www.treasury.govt.nz/ government/financialstatements/yearend/jun09/05.htm.

2025 Taskforce. 2009. Answering the \$64,000 Question: Closing the income gap with Australia by 2025 - First report of the 2025 Taskforce. Wellington: New Zealand Government. http://purl.oclc.org/nzt/r-1252.

Westpac Banking Corp. v. Commissioner of Inland Revenue 7 October 2009, Harrison J, HC Auckland CIV 2005-404-2843.

WHO. 2004. 'Causes of death.' Data and Statistics. World Health Organization. www.who.int/research/en (accessed 1 October 2009).

Williamson, O. 1985. The Economic Institutions of Capitalism: Firms, markets, relational contracting. New York: Free Press.

World Bank. 2001. World Development Report 2002: Building institutions for markets. New York: Oxford University Press. econ.worldbank.org/external/ default $/$ main pagePK $=64165259 \&$ theSitePK $=469372 \&$ piPK $=64165421 \&$ me nuPK=64166093\&entityID=000094946_01092204010635.

World Values Survey (n. d.) Online data analysis. www.wvsevsdb.com/wvs/ WVSAnalize.jsp.

Zak, P., and S. Knack. 2001. 'Trust and growth.' Economic Journal 111(470): 295321 . 